\title{
Олександр Юдін
}

\section{«ПЕРША» ФІЛОСОФІЯ І ЕСТЕТИКА МИХАЙЛА БАХТІНА: СПРОБА ПОДОЛАННЯ ТРАНСЦЕНДЕНТАЛЬНОГО ПІДХОДУ У ФІЛОСОФСЬКІЙ ДУМЦІ}

\section{Стаття перша}

Теоретична спадщина М. М. Бахтіна здолала довгий і непростий шлях до публікації й увійшла у науковий обіг приблизно за півстоліття по тому, як була створена (зокрема це стосується текстів, що містили філософські та естетичні засади його підходу), поставши при цьому певним науковим одкровенням. Від кінця 60-х років XX століття, коли праці Бахтіна почали друкувати європейськими мовами, вони одразу викликали жвавий інтерес, що й досі не відійшов у минуле. Подібно до того, як у 30-х роках XX століття дослідження у галузі літератури на Заході зазнали впливу російської формальної школи, що була одним із джерел формування структуралізму, так у 70-х ідеї Бахтіна (котрий свого часу був принциповим опонентом формалістів) виявилися співзвучними тенденціям у царині гуманітарних наук, пов'язаних із подоланням структуралізму. Гуманітарне мислення Бахтіна $з$ його широтою виявилося цікавим не тільки літературознавцям, але й філософам. Його ідеї плідно зіставлялися не тільки 3 ідеями його попередників і сучасників (тобто в історико-філософському аспекті), але й із концепціями М. Гайдегера [Давыдов, 1986; Назинцев, 1991], Л. Вітгенштайна, Дж. Остіна, Дж. Сьорла, Р. Рорті, Г.-Г. Гадамера [Бонецкая, 1995; Бялостоцки, 2010; Медведев, 1991], Ж. Дерида [Куюнжич, 1990; Караченцева, 1992; Холквист, 2010], Ж. Дельоза й Ф. Гватарі [Рыклин, 1992], М. Бланшо, Е. Левінаса [Понцо, 1995], В. Джеймса, Д. Г. Міда, Д. Дьюї [Эмерсон, 1993] та ін. Іншими словами, Бахтін виявився співзвучним і актуальним у контексті майже всіх впливових теперішніх філософських теорій і течій, здебільшого також тісно пов'язаних 3 літературознавством.

Зокрема, естетична теорія Бахтіна є одним із найвпливовіших теоретичних підходів у сучасному літературознавстві. Попри давнє створення, вона залишається цілком актуальною і робочою теорією, що в основних своїх положеннях не виявляє ознак старіння, не перетворюється на експонат історії теорії літератури.

Бахтінське гуманітарне мислення - це комплекс ідей, вироблених однією людиною, сказати б, одночасно на декількох поверхах, рівнях знання, які зазвичай

(C) О. Юдін, 2012 
знаходяться у віданні декількох дисциплін і, відповідно, різних фахівців. Воно охоплює рівні філософії, точніше, філософської онтології або першої філософії (моральна філософія, або архітектоніка події буття, за визначенням самого Бахтіна); естетики (естетична діяльність автора як діяльність завершення героя); теорії літератури (естетика словесної творчості, розробка понять пізнання естетичного об'єкта); нарешті, рівень історії літератури, тобто рівень емпіричних досліджень (цілком очевидно, що «Проблеми творчості/поетики Достоєвського», 3 деякими застереженнями «Творчість Франсуа Рабле і народна культура середньовіччя і Ренесансу», фрагменти праці про роман виховання та інші виростають з фундаментального багаторівневого теоретичного підходу і - що ще важливіше - розвивають і уточнюють його, відбивають еволюцію самого теоретичного виміру). До цього слід додати рівень або вимір філософії культури, який з'являється спочатку саме в емпіричних історико-літературних дослідженнях («Творчість Франсуа Рабле»), а потім отримує теоретичне оформлення (щоправда, не розгорнуте у великих працях i викладене здебільшого у фрагментарних i конспективних записах) у пізніх текстах. Причому на кожному рівні Бахтін виявляє свій оригінальний, неповторний підхід, і його, сказати б, втручання змінює кожне поле досліджень, яке після цього не можна уявити без внеску російського мислителя. (Це не стосується лише філософського рівня через невеликий обсяг єдиного суто філософського тексту Бахтіна, «До філософії вчинку», і пізнє оприлюднення останнього: він став доступним читачам лише у 1986 р., а перший переклад англійською мовою вийшов друком у 1993 р.) У цьому сенсі органічність філософсько-гуманітарної спадщини й мислення Бахтіна безпрецедентна за глибиною й опрацюванням теоретичного підходу (якщо мати на увазі під глибиною саме органічність взаємозв'язку пізнання конкретних емпіричних фактів історії літератури 3 теоретичними положеннями, дистанцію між фактами i теоретичними началами, розділену на декілька дисциплінарних рівнів, так би мовити, самостійно охоплену однією думкою).

Потрібність бахтінських ідей сучасній філософії та гуманітарним наукам зумовлена тим, що російський мислитель розробляв свої ідеї у діалозі й суперечці, насамперед, з західною, зокрема, з трансцендентальною філософією, заснованою I. Кантом.

Хоча, на позір, наукова спадщина Бахтіна має доволі строкатий і навіть суперечливий характер, більшість дослідників, що уважно й цілеспрямовано вивчали його праці, наполягають на іiі цілісності, хоча й тлумачать іiі по-різному. Про це писали В.С. Біблер [Библер, 1991: с. 90], В.Л. Махлін [Махлин, 1990], Н.К. Бонецька [Бонецкая, 1994: с. 17], М. Голквіст [Holquist, 2002: p. 13] та чимало інших [Некрасов, 1998: с. 97]

Доречно пригадати і пояснення самого Бахтіна, який у 1971 р., готуючи видання збірки своїх праць різних років, визначав єдність свого доробку через єдність «теми на різних етапах іï розвитку. Сдність ідеї, що перебуває в процесі становлення (розвивається). Звідси й певна внутрішня незавершеність багатьох моїх думок» [Бахтин, 1979: с. 360]. Тим більше це стосується текстів, що писалися майже одночасно. Хоча сам вчений не говорить про системність, а натомість визначає єдність свого науково-творчого шляху радше через єдність предмету («тема»), ніж єдність підходу, і наголошує на розвитку свого розуміння (становлення ідеї), - і ми вважаємо, що це не випадково, - тож слово «системність» слід застосовувати до 
бахтінської спадщини загалом з певними застереженнями (принаймні з таким, що тут не йдеться про свідому побудову, розробку різних частин системи). Проте саме до ранніх праць Бахтіна поняття системності є цілком застосовним. Можна навіть говорити про прагнення системності.

Ступенева розробка онтології, а слідом за нею естетики свідчить про філософську дисципліну розуму, вишколеного німецькою класичною філософією з ії неодмінним ототожненням філософії та систематичності, зокрема кантіанською традицією. Йдеться, насамперед, про Канта й Когена, в яких естетика слугувала завершенням системи і місцем розв'язання філософських дуалізмів, породжених протиставленням суб'єкта й об'єкта. Але вже на цьому, так би мовити, відрізку шляху бахтінської думки постає видимим саме становлення: тяглість думки і водночас зміщення іiі вузлів, зміна певних конфігурацій понять.

Бахтін також починає 3 констатації дуалізму. В його інтерпретації основний філософський дуалізм постає як протистояння двох світів - світу життя й світу культури, або буття-події та культури.

Проте, на відміну від кантіанської традиції, Бахтін шукає подолання цього дуалізму не у побудові системи, а взагалі у виході за межі теоретичного мислення. Дуалізм може бути подоланий лише практично. Спосіб такого подолання названий вже у першій газетній публікації Бахтіна 1919 р., невеличкій замітці «Мистецтво і відповідальність». Хоча цей текст як такий не має самостійного філософського значення, він дуже важливий саме як прояв того самого становлення, розвитку ідеї.

Вже тут з'являється ключова бахтінська категорія відповідальності. У «Мистецтві й відповідальності» конфлікт між життям і культурою ще не сформульований, а лише намічений. Тут наявні взаємонакладення понять і поняттєвих опозицій, що пізніше (у «Філософії вчинку») будуть чітко розрізнені. Вихідна конфігурація понять тут суттєво інша і дещо ближча до неокантіанської позиції, ніж у «Філософії вчинку». По-перше, роль найширшої, всеохопної категорії тут відіграє поняття культури: «Три царини людської культури - наука, мистецтво й життя - досягають єдності лише в особистості, що залучає їх до своєї єдності» [Бахтин, 2003: с. 5]. Отже, життя постає поруч, можна сказати, пліч-о-пліч не тільки з мистецтвом, але й з наукою - як щось однопорядкове їм, а культура вииявляється їхнім спільним знаменником. Також поняття культури тут постає радше відповідником поняття особистості. Принаймні тут немає ані явного, ані імпліцитного протиставлення.

Натомість у «Філософії вчинку» всі форми культури протиставляються буттюподії: «Спільним моментом дискурсивного теоретичного мислення (природничонаукового й філософського), історичного зображення-опису та естетичної інтуїції... $\epsilon$ таке. Всі названі діяльності запроваджують принциповий розкол між змістомсенсом даного акту-діяльності та історичною дійсністю його буття, його дійсним унікальним переживанням, внаслідок чого цей акт втрачає своє ціннісне наповнення та єдність живого становлення й самовизначення» [Бахтин, 2003: с. 7].

Тісно пов'язаним і відповідним поняттю культури у «Мистецтві й відповідальності» $є$ поняття сенсу. «Ціле називається механічним, якщо окремі його елементи поєднані у просторі й часі зовнішнім зв'язком, а не проникнуті внутрішньою єдністю сенсу» [Бахтин, 2003: с. 5]. Отже, йдеться про (1) єдність сенсу, (2) єдність культури, (3) єдність особистості як про поняття одного порядку, спорідненні поняття. У «Філософії вчинку» констатується розкол між змістом-сенсом та дійсніс- 
тю. Сенсова сторона (йдеться про акт естетичної діяльності) «претендує самовизначитися уповні й остаточно в єдності тієї чи тієї сенсової області: науки, мистецтва, історії» [Бахтин, 2003: с. 7].

I тільки співвідношення між життям, мистецтвом і відповідальною особистістю (розрив між життям і мистецтвом долається через відповідальність особистості) без змін і уточнень переходить у філософський трактат: «Мистецтво і життя не єдині, але повинні стати єдиним в мені, в єдності моєї відповідальності» [Бахтин, 2003: c. 6]. Ця опозиція увійде до (переросте в) більш широкої опозиції життя і культури. Власне, текст «Мистецтво й відповідальність» зосереджений саме на проблемі невідповідності, протистояння мистецтва й життя (про науку й культуру тут ідеться лише одного разу), отже, ймовірно, саме вона була вихідною проблемною точкою подальшої рефлексії й витоком формування загальнішої і принциповішої філософської опозиції, яка постає вже на першій сторінці тексту «До філософії вчинку».

Вперше опублікований у 1986 р., цей текст виглядав як цілковито самобутній та дистанційований від відомих філософських традицій. Проте, ретроспективно оцінюючи шлях філософської думки вченого, можна бачити, що Бахтін рухався у напрямі, паралельному рухові західної філософії: долаючи суб'єкт-об'єктний мисленнєвий підхід, властивий західній філософії Нового часу, відштовхуючись від філософії свідомості й переходячи до філософії буття і, зрештою, до філософії мови, яка постає, водночас, герменевтикою і філософією культури. Це дозволило російському вченому стати «сучасником» постструктуралістського етапу розвитку західної гуманітарної думки, тобто включитися у діалог з мислителями цього періоду. Слід зауважити, що сам Бахтін, цілком імовірно, не ставив перед собою завдання саме у такій формі (подолання суб'єкт-об'єктного підходу), проте абсолютно очевидно, що його критика спрямована проти раціоналізму новочасної філософії, проти іiі «теоретизму», відповідального за вказаний розкол між життям та культурою i, зокрема, пов'язаного з кантівською філософією ${ }^{1}$.

Гідним подиву є те, що, по-перше, Бахтін рухався цим шляхом 3 деяким випередженням філософської еволюції Заходу i, по-друге, пройшов сам шлях, який у західному філософському ландшафті вкладається у декілька біографій найвідоміших його постатей. Щоправда, у Бахтіна цей рух, точніше, його вияви, продукти наукової творчості мали уривчастий і навіть дещо, так би мовити, езотеричний характер через особливості біографії.

Зокрема, найбільш відповідною текстові «До філософії вчинку» - у сенсі зазначеної еволюції філософських засад - $\epsilon$ праця Мартина Гайдегера «Буття і час» ${ }^{2}$. Не

${ }^{1}$ Імовірно, саме Кант і був головною мішенню для Бахтіна. Період написання текстів, що склали «Філософію вчинку» та «Автора і героя в естетичній діяльності», був періодом інтенсивного спілкування Бахтіна у так званому Невельському колі однодумців, i, за багатьма свідченнями, однією з головних тем обговорення слугувала саме філософія кьонігсберзького мислителя. Один із найвідоміших дослідників наукової творчості Бахтіна, М. Голквіст, зокрема, зауважив у передмові до першої публікації тексту «До філософії вчинку» англійською мовою: «...цей текст спроба детрансценденталізувати Канта i, зокрема, вийти за межі кантівського формулювання категоричного імперативу» [Bakhtin, 1993: p. ix].

${ }^{2}$ Першим філософське зіставлення Бахтіна 3 Гайдегером здійснив відомий російський історик філософії та соціології Юрій Давидов [Давыдов, 1986]. Прагнучи визначити місце Бахтіна у філософському ідейному універсумі, дослідник тлумачить російського мислителя як своєрідний «випереджальний коректив» до філософії Гайдегера. Щоправда, існує думка про недоречність, навіть неприпустимість порівняння Бахтіна і Гайдегера [Назинцев]. 
заперечуючи принципових відмінностей між двома феноменологіями - архітектонікою події буття Бахтіна й аналітикою екзистенції Гайдегера, - ми хочемо, все ж, відзначити суттєву подібність, по-перше, зазначеної еволюції західної філософії i, по-друге, філософського шляху російського вченого. I Бахтін, i Гайдегер використовують феноменологічний метод для опису не свідомості, а буття людини. I в обох випадках звернення до категорії буття крізь призму феноменології стало проміжною ланкою переходу до філософії мови. Звісно, з тим істотним застереженням, що філософія мови була лише моментом філософської позиції Бахтіна, яку не можна вписати у жодний з напрямів, що сформувалися в західній філософії. Спеціально філософії мови (або «металінгвістиці», за термінологією самого вченого) присвячено лише дві праці - «Проблема мовленнєвих жанрів» і так званий девтероканічний, за визначенням Сергія Аверинцева, текст «Марксизм і філософія мови», виданий під псевдонімом В. Н. Волошинов. Філософія мови Бахтіна становить частину його загальної філософії культури, яку найчастіше характеризують через поняття діалогу, або діалогізму [Holquist, 2002]. Власне, Гайдегера (після так званого повороту) теж не можна назвати філософом мови. Він залишається філософом буття, але доступ до цього буття вже отримується не через феноменологію, а через герменевтику, не через опис наочно явленого, а через вслуховування у мову. Проводячи паралель між Бахтіном і Гайдегером, ми хочемо лише виявити і підкреслити певну об'єктивність розвитку методології.

Для обох мислителів звернення до теми буття зумовлене засвоєнням та використанням Гусерлевого феноменологічного методу. I для Бахтіна («До філософії вчинку» та почасти «Автор і герой в естетичній діяльності» як продовження першої), і для Гайдегера («Буття і час») праці, присвячені темі буття, виявилися певною мірою моментом розвитку філософської позиції. Доречно зазначити таку річ. Гайдегер не закінчив «Буття і час» начебто 3 причин неадекватності філософської мови для формулювання сенсу буття. Натомість пізній Гайдегер переходить до так званого міфопоетичного мислення про буття, яке інколи характеризують як поезію понять. Але обидві згадані праці Бахтіна фактично теж лишились незавершеними. Сам Бахтін, як відомо, не робив спроб їх оприлюднити, й обидві не були надруковані за його життя. Звісно, у випадку Бахтіна далися взнаки зовсім інші суспільно-політичні умови. Проте очевидно, що поняттєвий апарат, розроблений Бахтіном у «Філософії вчинку», не виявляє себе прямо у подальших його дослідженнях. Поняття «події буття», «архітектоніки події буття» не виявляють себе як методологічні опори в його пізніших текстах, а лише відчуваються як певні вихідні точки, або ж, сказати б, перехідні положення. Можна зважитись на твердження: якби цุі тексти лишилися невідомими, реконструювати викладену в них філософію як методологію з самих лише «Проблем поетики Достоєвського» та «Творчості Франсуа Рабле і народної культури середньовіччя й Ренесансу» було б неможливо.

Отже, об’єктивна тенденція філософського розвитку Бахтіна і Гайдегера, полягає у переході від феноменології свідомості до феноменології буття, а згодом - у виявленні філософської недостатності безпосереднього опису буття й, звідси, у переході до герменевтично орієнтованої філософії, тобто філософії, що враховує опосередкованість будь-якого феноменологічного опису виміром мови (у випадку Гайдегера це перехід до герменевтики буття, у випадку Бахтіна - перехід до герме- 
невтично орієнтованої філософії культури) ${ }^{3}$. Зв'язок Бахтіна 3 феноменологією Гусерля є незаперечним. Сам Бахтін прямо засвідчує свою прихильність до феноменологічного методу, визначаючи свою першу філософію як феноменологію світу вчинку [Бахтин, 2003: с. 31]. Без таких понять, як «акт свідомості», «настанова свідомості», що ними постійно користується Бахтін, і взагалі без опори на інтуїтивізм, його опис-аналіз події буття був би неможливий ${ }^{4}$. Опис естетичного процесу, формулювання понять естетичного завершення, естетичного об’єкта у праці «Автор і герой в естетичній діяльності» спирається на феноменологічний метод і на першу філософію Бахтіна, тобто на феноменологію події буття і розроблений у ній поняттєвий апарат. Отже, без опори на феноменологічний метод були б неможливі також естетика Бахтіна та його теорія автора.

Вихіднним пунктом і спонукою до розробки «першої філософії» для Бахтіна слугує проблема розколу між культурою і життям. Власне, саме це протистояння, вірогідно, бере свій початок від протиставлення Кантом світу феноменів та світу речей самих по собі. Цей дуалізм зумовлений протистоянням суб'єкта пізнання і речей самих по собі. Перший конструює свій об'єкт за допомогою, 3 одного боку, понять розсудку, з іншого - чуттєвих вражень, що надходять від речей самих по собі. І оскільки суб'єкт пізнання у філософії Канта мислиться не як індивід, а як сутність людини, тобто як універсальний суб'єкт, або - в його термінології - трансцендентальний суб'єкт, можна сказати, що останній є синонімом людської культури, хоча експліцитно в філософії Канта таке визначення не сформульоване.

Однією з головних філософських доктрин, що мали вплив на формування науково-філософського мислення Бахтіна була Марбурзька школа неокантіанства $^{5}$ [див.: Исупов, 1990: с. 30, 37; Каган, 1991: с. 17; Чаплеєвич, 2008: с. 194 (тут також посилання на дослідження цієї теми); Brandist, 2002: c. 13-14; Clark, 1984: p. 1; Holquist, 2002: p. 4-6], зокрема, праці їі засновника і лідера Германа Когена, що присвятив більшу частину свого життя способам уникнути дуалізму феноменів і речей самих по собі. Висновок Когена: слід відмовитись від існування речей самих по собі; форми чуттєвості, простір і час, є похідними від категорій розсудку, тобто є формами мислення, натомість об'єкт пізнання повністю конструю-

${ }^{3}$ Ми вже згадували Г.Г. Шпета, котрий також безпосередньо був учнем Гусерля. Йому, зокрема, належить найбільш класичний виклад засад феноменологічної філософії російською мовою, книжка «Явище і сенс» (1914), в якій він постає правовірним феноменологом. Але надалі, у зв'язку з дослідженням проблем історичної науки, Шпет поступово переходить на герменевтичні позиці, що, зокрема, виявилося у його працях «Герменевтика та ії проблеми» (1919) та «Внутрішня форма слова» (1927). Можна навести й інші приклади подібної філософської еволюції. Але прикметність зіставлення Бахтіна, Гайдегера і Шпета полягає саме у тому, що вони рухалися у одному напрямі, не маючи попередників і цілковито незалежно один від одного.

${ }^{4}$ Один 3 дослідників цієї теми зазначає: «Феноменологічний характер раннього дослідження Бахтіна, присвяченого філософії вчинку, є доволі очевидним» [Исаков, 1991: с. 90]. Проте водночас характер і міра цього зв'язку вивчені дуже недостатньо, i той самий дослідник зауважує, що питання про міру закоріненості філософської позиції Бахтіна у вказаній традиції лишається відкритим [там само]..

5 Зрештою, у роки перебування М.М. Бахтіна у Невелі навколо нього і його найближчих друзів та однодумців Л.В. Пумпянського і М.I. Кагана склався філософський семінар, який сучасники називали «кантівським»; зрештою, М.І. Каган навчався у Марбурзі в Г. Когена і повернувся на батьківщину доктором Марбурзького університету [Каган, 2010: с. 37]. 
ється свідомістю. Інакше кажучи, об'єкт пізнання, за Когеном, цілковито породжений людською культурою, втіленою у свідомості (що постає у формах розуму, волі та почуття).

Власне, філософія Когена повністю знаходиться у рамцях суб'єкт-об'єктної парадигми. Це філософія свідомості, цілковито відокремленої від буття. До останнього вона має лише один стосунок: як до свого предмета. Коген вибудовує свою філософію як систему, ідучи за Кантом і намагаючись лише усунути суперечності, наявні в Канта. Іншими словами, створює систему більш систематичну, ніж кантівська (система складається 3 трьох частин: «Логіки чистого пізнання», «Етики чистої волі» та «Естетики чистого почуття»). Естетика для Когена - лише «третій член системи філософії». I сама філософська естетика визначається ним «як систематична естетика» [Cohen, 1912: S. XI]. В цілому це естетика понять. Коген займається поняттями чистоти естетичної свідомості, законів чистого почуття, поняття естетичної закономірності як такої ${ }^{6}$ будови естетичної свідомості, прекрасного, піднесеного, гумору (останні три поняття є, за Когеном, основними категоріями естетики) тощо [див. Cohen, 1889: S. 144f., 222f.; Cohen, 1912: розд. 3, 4, 5 відповідно]. У суто кантіанському дусі Коген керується трансцендентальним методом, намагається визначити логічні засади духовної діяльності людини i, зокрема в естетиці, намагається визначити умови можливості чистого почуття, або ж умови «можливості естетичної свідомості та предмета для естетичної свідомості» ${ }^{7}$ [Cohen, 1912: S. 84; див. також: Зотов, 1988: с. 127; Антисери, 1994: с. 279]. Коген принципово відділяє філософську естетику від мистецтвознавства [Cohen, 1912: S. XI] ${ }^{8}$. Тож головною його турботою була систематизація понять. Загалом він виходить 3 тези про єдність людської природи і оперує поняттями, характерними для класичної естетики. Вимір людської діяльності та соціальний вимір у нього відсутні. Поняття свідомості для нього тотожне поняттю культури 9 . Інакше кажучи, філософія Когена повністю лишається у ХІХ столітті.

Проте важливо відзначити, що певні положення естетики Когена, імовірно, вплинули на естетику Бахтіна, зокрема, як ми далі побачимо, у ній (принаймні якщо спиратись на текст «Автор і герой в естетичній діяльності») зберігається

${ }^{6}$ Перший російський філософ-неокантіанець Б. О. Фохт узагальнював завдання естетики Когена так: «...вже в Кантовій «Критиці сили судити» і ще більше в Когеновій «Естетиці чистого почуття» все зводиться до того, щоб відкрити, визначити й обгрунтувати поняття естетичної закономірності в її зв'язку, відповідності, своєрідній відмінності й водночас внутрішній подібності 3 поняттям закономірності взагалі як загальної бази й принципу всієї трансцендентальної філософіï» [Фохт, 2003: с. 213].

7 На думку Б.О. Фохта, «у Когена на перший план з усією енергією висувається саме термін свідомості» [Фохт, 2003: с. 250].

8 Хоча в цілому за багатством змісту естетика Когена, мабуть, не поступається естетиці Гегеля. Зокрема, дві третини «Естетики чистого почуття» становить саме аналіз літератури і видів мистецтв.

9 Основним органом Марбурзької неокантіанської школи був часопис Philosophische Arbeiten. У першому числі цього часопису Г. Коген і П. Наторп чітко сформулювали свою платформу: «Той, хто пов'язаний з нами, стоїть разом з нами на засадах трансцендентального методу... Для нас філософія прив'язана до факту науки мірою розвитку останньої. Отже, філософія для нас - це теорія принципів науки, а відтак і всієї культури» [цит. за: Beck, 2006: p. 542]. Очевидно, що марбурзькі філософи стояли на позиціях дуже далеких від філософа «буття-події», і до них також можна застосувати його критику теоретизму (див. далі). 
Когенова теза про естетичну активність свідомості як щось первинне, що не може бути виснуваним з інших логічних або історичних передумов. (Коген говорить про «розум мистецтва» як первинне (Ursprünglich) у душі) [див.: Cohen, 1912: S. 70-71; також: Лекции, 1976: c. 43]. Також надзвичайно важливу роль в естетиці Бахтіна відіграє розроблене Когеном поняття «естетичного почуття любові» [див.: Cohen, 1912: S. 174-185]. Саме воно постає у Бахтіна принциповим обгрунтуванням сенсу естетичної діяльності. Не можна не згадати про те, що саме неокантіанська філософська традиція стала джерелом поняття цінності, яке відіграє важливу роль в естетиці («Автор і герой») і загалом гуманітарній методології («Проблема тексту в гуманітарних науках») Бахтіна [див.: Столович, 1989:]. Також Коген уже розмірковував про відношення я та іншого [Каган, 1991: с. 17]. Зрештою, причетність до кантіанської (неокантіанської) традиції і певна залежність від неї виявляється у Бахтіна, насамперед, у наслідуванні кантівської, доведеної до граничної чіткості Когеном, тріади філософських дисциплін i, відповідно, трьох царин буття і трьох способів ставлення суб'єкта до дійсності - пізнання, тобто теоретичного ставлення до світу: практичної або моральної філософії; естетики. Саме 3 цієї традиції походить тлумачення ключових для естетики Бахтіна понять змісту (як дійсності пізнання і вчинку) та форми (як естетичного оформлення дійсності пізнання i вчинку) [Бахтин, 2003: с. 289 ${ }^{10}$.

Також, імовірно, саме в Германа Когена Бахтін запозичив одне 3 ключових понять своєї естетики, що донині зберігає актуальність, а саме поняття завершення [Cohen, 1912: S. 209]. Не можна також не відзначити певного перетину між неокантіанською філософією Когена та феноменологічною філософією Едмунда Гусерля, що вирішально вплинула на методологічний підхід Бахтіна як у царині філософії, так й у царині естетики та теорії літератури. Це стосується тези про «іманентність» буття свідомості, про що писали дослідники неокантіанської філософії [Буржуазная философия, 1977: с. 73]. Утім, це не заважає бачити суттєві гносеологічні й методологічні відмінності між ними. Адже Коген методологічно лишається у рамцях класичної філософії: хоча він, як послідовник Канта, апелює до трансцендентального методу, багато в чому цей останній нагадує спекулятивний метод Гегеля. Загалом, як уже йшлося, Коген займається логізуванням, тобто узгодженням абстрактних понять на основі їх абстрактних логічних визначень, зазвичай без опори на емпіричне чи, скажімо, сутнісне (як у Гусерля) споглядання. Також, на відміну від Гусерля, Коген розуміє свідомість не як живе буття («жива свідомість» - поняття, яким часто користується Бахтін), а як систематичну єдність, тобто йдеться власне не про свідомість, а про теоретичне поняття свідомості, або ж про зміст уявлення ${ }^{11}$. Тож у філософських розмірковуваннях Когена домінує умоглядний підхід, а його філософську пози-

${ }^{10}$ Коген визначає художній твір саме через обов'язкове поєднання в ньому дійсності пізнання i вчинку: «Твір мистецтва повинен обов'язково бути, по-перше, предметом природи і як такий предметом пізнання природи. I, по-друге, він має бути на додаток до першої умови і у внутрішньому зв'язку з нею, - також предметом моральності й має породжуватися як такий чистий предмет морального пізнання. Обидві ці умови залишаються обов'язковими основними умовами і самого твору мистецтва, і художньої творчості» [Cohen, 1912: S. 80].

11 «Свідомість, розглянута з трансцендентальної точки зору, $\epsilon$ не лише первинною формою закону, але найближчим чином виявляє себе як втілення методів, що породжують досвід в усьому його науковому складі, ба більше з усіма його змістами» [Cohen, 1885: S. 142]. 
цію можна цілком обгрунтовано віднести до ідеалізму ${ }^{12}$. Все це є досить далеким від інтуїтивізму Гусерля, що став безперечною методологічною основою філософії та гуманітарного мислення Бахтіна.

Отже, попри ці окремі впливи, запозичення певних поняттєвих конфігурацій та загальну повагу до Когена і його філософії, у Бахтіна зберігається протиставлення життя й культури - аспект, повністю відсутній у Когена. Відтак можна сказати, що формулювання цієї проблеми у Бахтіна певною мірою відновлює кантівський дуалізм. Хоча сформульована вона не як проблема пізнання, пізнавального дуалізму, а як протистояння в історичній дійсності, тобто як проблема не гносеологічна, а почасти онтологічна, почасти історична. Причому в Бахтіна ця опозиція зазнає певного переакцентування, в якому відчувається вплив філософії життя, зокрема такого її представника, як Георг Зімель.

Отже, спираючись саме на філософію життя і феноменологічний метод, Бахтін знаходить оригінальний шлях за межі властивого трансцендентальній філософії суб'єкт-об'єктного дуалізму і рухається до філософії буття, яку буде розглянуто у другій частині статті.

\section{СПИСОК ЛІТЕРАТУРИ}

Антисери Д., Реале Дж. Западная философия от истоков до наших дней. Т. 4: От романтизма до наших дней. - М.: Петрополис, 1994. -880 с.

Бахтин М.М. Собрание сочинений: В 7-ми т. - М.: Издательство русские словари; Языки славянской культуры. - Т. 1: Философская эстетика 1920-х годов, 2003. - 960 с.

Библер М.С. Михаил Михайлович Бахтин, или Поэтика культуры. - М.: Гнозис, 1991. $170 \mathrm{c}$.

Бонеикая Н.К. М. Бахтин в 1920-е годы // Диалог. Карнавал. Хронотоп. - Витебск: Изд-во Витебского пединститута. - 1994. - № 1. - С. 16-62.

Бонеикая Н.К. М. Бахтин и идеи герменевтики // Бахтинология: Исследования, переводы, публикации. - СПб.: Алетейя, 1995. - С. 32-42.

Буржуазная философия кануна и начала империализма. - М.: Высшая школа, 1977. - 424 с.

Бялостоики Д. Разговор как диалогика, прагматика и герменевтика: Бахтин, Рорти, Гадамер // Михаил Михайлович Бахтин. - М.: РОССПЭН, 2010. - С. 126-142.

Давыдов Ю. У истоков социальной философии М.М. Бахтина. // Социологические исследования. - М.: 1986. - №2. - С. 170-181.

Зотов А.Ф., Мельвиль Ю.К. Буржуазная философия середины XIX - начала XX века. - М.: Высшая школа, 1988. - $520 \mathrm{c}$.

Исаков А.Н. Философия поступка Бахтина и трансцендентально-феноменологическая традиция // М.М. Бахтин и философская культура XX века (Проблемы бахтинологии). Вып. 1. Часть 1. - С.-Петербург: Издательство «Образование», 1991. - С. 90-102.

Исупов К.Г. О философской антропологии М.М. Бахтина // Бахтинский сборник. Вып. І: Сб. ст. - М.: Прометей, 1990. - С. 30-46.

Каган М.С. Идея диалога в философско-эстетической концепции М. Бахтина: закономерности формирования, духовный контекст и социокультурный смысл // М.М. Бахтин и философская культура XX века (Проблемы бахтинологии). Вып. 1. Часть 1. - С.Петербург: Издательство «Образование», 1991. - С. 17-31.

Каган Ю.М. Люди не нашего времени // Михаил Михайлович Бахтин. - М.: РОССПЭН, 2010. - C. 34-46.

${ }^{12}$ На чому, власне, наполягає і сам Коген. Заключний розділ його фундаментальної праці «Кантова теорія досвіду» називається «Система критичного ідеалізму» [див.: Коген, 2006; Cohen, 1885: S. 575-616]. 
Караченцева И.С., Караченцева Т.С. М.М. Бахтин и Ж. Деррида: фигура читателя // М.М. Бахтин: эстетическое наследие и современность: межвузовский сборник научных трудов. - Ч. II. - Саранск: Издательство Мордовского университета, 1992. - С. 183-189.

Коген Г. Теория опыта Канта. Гл. 16. Система критического идеализма. / Пер. В. Н. Белова // Вопросы философии. - 2006. - № 4. - С. 151-173.

Куюнжич Д. Смех как «другой» у Бахтина и Деррида // Бахтинский сборник. Вып. I: Сб. ст. - М.: Прометей, 1990. - С. 83-107.

Лекuии по истории эстетики. Книга 3, часть 1. - Ленинград: Издательство Ленинградского университета, 1976. - $192 \mathrm{c}$.

Махлин В.Л. «Диалогизм» М.М. Бахтина как проблема гуманитарной культуры XX века // Бахтинский сборник. Вып. І: Сб. ст. - М.: Прометей, 1990. - С. 107-129.

Медведев В.И. Проблема контекста у М. Бахтина и в западной философии языка // M.М. Бахтин и философская культура XX века (Проблемы бахтинологии). Вып. 1. Часть 1. - С.-Петербург: Издательство «Образование», 1991. - С. 118-127.

Назинцев В.B. Мыслитель Бахтин и теоретик Хайдеггер // М.М. Бахтин и философская культура XX века (Проблемы бахтинологии). Вып. 1. Часть 1. - С.-Петербург: Издательство «Образование», 1991. - С. 102-112.

Некрасов С.В. Высказывание как предмет феноменологического рассмотрения (Бахтин и Гуссерль) // Бахтинские чтения - II. Материалы Международной научной конференции: Витебск, 24-26 июня 1996 г. - Витебск: Изд-во Витебск. ун-та, 1998. - С. 97-104.

Понио A. «Другость» у Бахтина, Бланшо и Левинаса // Бахтинология: Исследования, переводы, публикации. - СПб.: Алетейя, 1995. - С. 61-78.

Рыклин М. К. Сознание и речь в концепции М.М. Бахтина // М.М. Бахтин как философ. М.: Наука, 1992. - С. 175-189.

Столович Л.Н. М.М. Бахтин и проблема ценности // Эстетика М.М. Бахтина и современность. - Саранск: 1989. - С. 25-27.

Фохт Б.А. О постановке основной проблемы эстетики у Канта и Когена в связи с критикой основных понятий и принципов, примененных Кантом к ее решению // Б.А. Фохт. Избранное (из философского наследия). - М.: Прогресс-Традиция, 2003. - С. 195-262.

Холквист M. Услышанная неслышимость: Бахтин и Деррида // Михаил Михайлович Бахтин. - М.: РОССПЭН, 2010. - С. 164-190.

Чаплеєвич $\epsilon$. Діалогічне мислення Михайла Бахтіна // Література. Теорія. Методологія. Київ: Видавничий дім «Києво-Могилянська академія», 2008. - С. 176-197.

Эмерсон $K$. Американские философы в свете изучения Бахтина (Уильям Джеймс, Джордж Герберт Мид, Джон Дьюи и Михаил Бахтин по поводу философии поступка) // Диалог. Карнавал. Хронотоп. - Витебск: Издательство Витебского пединститута, 1993. № 2-3. - C. 5-18.

Bakhtin M.M. Toward a philosophy of the act. - University of Texas Press, 1993. - $106 \mathrm{p}$.

Beck L.W. Neo-Kantianism // Encyclopedia of Philosophy / Donald M. Borchert, eds. - Thomson Gale, 2006. - Vol. 6. - P. 539-546.

Brandist C. The Bakhtin Circle: Philosophy, Culture and Politics / Craig Brandist. - London: Pluto Press, 2002. $-221 \mathrm{p}$.

Clark K., Holquist M. Mikhail Bakhtin. - Harvard University Press, 1984. - 398 p.

Cohen H. Kants Theorie der Erfahrung / 2. Auflage. - Berlin: Ferd. Dümmlers Verlagsbuchhandlung, 1885. -616 S.

Cohen H. Kants Begründung der Aesthetik. - Berlin: Ferd. Dümllers Verlagsbuchhandlung, 1889. $-434 \mathrm{~S}$.

Cohen H. System der Philosophie. T. 3: Ästhetik des reinen Gefühls. - Bd. 1. - Berlin: Cassirer, 1912. - XIV, $402 \mathrm{~S}$.

Holquist M. Dialogism. Bakhtin and his World. - London and New York: Routledge, 2002. $224 \mathrm{p}$.

Стаття одержана редакцією 25.05.2012 
Alexander Yudin (Kyiv)

\section{Mikhail Bakhtin's “First” Philosophy and Aesthetics as an Attempt to Overcoming the Transcendental Approach in Philosophical Thought}

The article analyses M. M. Bakhtin's early works "Art and Responsibility" and "Toward a Philosophy of Act" which show that the philosophical way of Russian thinker was essentially parallel to the path of Western philosophy from Heidegger to post-structuralism and at the same time was an original attempt to overcome the transcendental approach in philosophy and aesthetics. Bakhtin worked out his original "first" philosophy of being or moral philosophy as polemically opposed to the Western philosophy of mind and especially to Kant's philosophy. But it was not free from certain transcendental moments connected with the orientation on the phenomenological method which later caused Bakhtin's evolvution towards hermeneutical philosophy of language and culture.

Alexander Yudin, PhD in philology, docent at the Department of Russian and foreign literature, National Pedagogical Dragomanov University.

Олександр Юдін, кандидат філологічних наук, дочент кафедри російської та зарубіжної літератури Національного педагогічного університету ім. М. П. Драгоманова.

Александр Юдин, кандидат филологических наук, дочент кафедры русской и зарубежной литературы Национального педагогического университета им. Н. П. Драгоманова. 